\title{
Epibryon kondratyukii sp. nov., a new algicolous fungus, and notes on rare lichenicolous fungi collected in Southern Ukraine
}

\author{
Valeriy V. Darmostuk ${ }^{1,2} \&$ Alexander Ye. Khodosovtsev ${ }^{1}$ \\ ${ }^{1}$ Kherson State University, 27 Universytetska Str., 73000 Kherson, Ukraine. \\ E-mail: valeriy_d@i.ua \\ ${ }^{2}$ Nizhnedneprovskiy National Nature Park, 136-a Universytetska Str., 73000 Kherson, Ukraine
}

\begin{abstract}
The new algicolous fungus Epibryon kondratyukii sp. nov. grows on Coccomyxa-like films on leaves of Polytrichum piliferum in Southern Ukraine. The species is characterized by sessile black setose pseudothecia, short 0-2-celled paraphysoids, 8-spored fissitunicate asci and hyaline 0-1-septate ascospores. The lichenicolous fungi Adelococcus interlatens, Ascochyta candelariellicola, Clypeococcum psoromatis, Epithamnolia rangiferinae, Lawalreea lecanorae, Llimoniella adnata, Merismatium decolorans, Sphaerellothecium cladoniae, Stigmidium bellemerei, S. ramalinae and Weddellomyces epicallopisma are new to the mycobiota of the Ukraine. Cladonia foliacea is a new host for Epithamnolia rangiferinae, Lecidea fuscoatra for Katherinomyces cetrariae, and Flavoplaca austrocitrina for Weddellomyces epicallopisma.
\end{abstract}

Keywords: Ascochyta, Epibryon, Epithamnolia, Katherinomyces

\section{INTRODUCTION}

The studies on diversity of lichenicolous fungi in the steppe zone of Ukraine started at the end of the last century (Kondratyuk \& Khodosovtsev, 1997). Currently, this research is one of the main projects of the mycological investigation in Southern Ukraine (e.g. Khodosovtsev \& Darmostuk, 2016, 2017; Darmostuk \& Khodosovtsev, 2017; Darmostuk et al., 2018). Eleven species of lichenicolous fungi new to Ukraine were recently collected and identified. The recently described Katherinomyces cetrariae (Khodosovtsev et al., 2016) was found on a new host. In addition, we found a fungus with small perithecia growing on algal Coccomyxa-like films on leaves of Polytrichum piliferum Hedw. that we describe as new to science in this paper.

\section{MATERIAL AND METHODS}

The specimens were examined by standard microscope techniques using LOMO microscopes MBS-1 and MICROMED-2. Microscopical examination was done in water, $10 \% \mathrm{KOH}$ $(\mathrm{K})$, and Lugol's iodine solution, directly (I) or after pretreatment with $\mathrm{KOH}(\mathrm{K} / \mathrm{I})$, or Brilliant Cresyl Blue (BCr). The measurements were made in water with an accuracy of $0.5 \mu \mathrm{m}$ for ascospores, asci, conidia, conidiogenous cells, conidiophores, and ascomatal and pycnidial wall cells, and $5 \mu \mathrm{m}$ for ascomata and pycnidia. The measurements are given as (min-)x-SD -
$\mathrm{x}+\mathrm{SD}(-\max )$, were $\mathrm{x}$ is the average and $\mathrm{SD}$ is the standard deviation. The photographs were taken with a Levenhuk C510 NG camera. All examined specimens are deposited in the lichenological herbarium of Kherson State University (KHER) and M.G. Kholodny Institute of botany NAS of Ukraine (KW). The new species to Ukraine are indicate with asterisk (*).

\section{The species}

*Adelococcus interlatens (Arnold) Matzer \& Hafellner

Specimen examined. Ukraine. Kherson region, Vysokopillya district, near Nataliino village $47^{\circ} 28^{\prime} 40.9^{\prime \prime} \mathrm{N} 33^{\circ} 20^{\prime} 41.4^{\prime \prime} \mathrm{E}$, alt. $25 \mathrm{~m}$, on thallus of Sarcogyne regularis Körb. growing on marl limestone, 5 May 2018, A. Khodosovtsev, V. Darmostuk (KHER 12145).

Notes. The species has been reported from Europe on endolithic thalli of calcicolous lichens, such as Clauzadea immersa (Hoffm.) Hafellner \& Bellem., Hymenelia prevostii (Duby) Kremp. and Sarcogyne regularis (Arnold, 1879, Matzer \& Hafellner, 1990, Navarro-Rosinés, 1992).

*Ascochyta candelariellicola D. Hawksw. \& Kalb Specimens examined. Ukraine. Mykolaiv region, Ochakiv district, Berezan Island, 46³6'04.0” N $31^{\circ} 24^{\prime} 36.1^{\prime \prime E}$, alt. 5 m, 20 July 2018, A. Khodosovtsev, V. Darmostuk (KHER 11663); Kherson region, Kalanchak district, Khorly village, $46^{\circ} 04^{\prime} 52.8^{\prime \prime} \mathrm{N}$ 
33¹7'57.2"E, alt. 9 m, on Populus, 8 August 2017, V. Darmostuk (KHER 11316). Both specimens inhabited the apothecia of Candelariella aurella (Hoffm.) Zahlbr.

Notes. Our specimens fit the concept of Ascochyta candelariellicola (Hawksworth \& Kalb, 1992). The species is characterized by globose, immersed, black conidiomata up to $60 \mu \mathrm{m}$ in diameter, ampulliform hyaline conidiogenous cells (3.2-)3.6-4.8(-5.4) $\mu \mathrm{m}(n=10)$ and hyaline broadly ellipsoid (1-)3-septate conidia $(8.4-) 10.2-13.0(-15.8) \times(2.8-) 3.0-3.2(-3.8) \mu \mathrm{m}$ $(n=30)$. It grows in the hymenium of Candelariella aurella, infected apothecia of which become decolorized. Ascohyta candelariellicola was known only from the type locality in Mexico. It is new to the Europe.

\section{*Clypeococcum psoromatis (A. Massal.) Etayo}

Specimens examined. Ukraine. Autonomous Republic of Crimea, Chornomorsk district, Tarkhankut peninsula, $45^{\circ} 25^{\prime} 33.5^{\prime} \mathrm{N} 32^{\circ} 32^{\prime} 20.6^{\prime \prime} \mathrm{E}$, on soil, 12 September 1994, A. Khodosovtsev (KHER 4952 sub Squamarina cartilaginea); Edukuyskii (Leninskii) district, cape Opuk, $45^{\circ} 02^{\prime} 30.4^{\prime \prime} \mathrm{N} 36^{\circ} 13^{\prime} 27.6^{\prime \prime} \mathrm{E}$, on limestone, 11 September 1994, A. Khodosovtsev (KHER 12147). Both specimens inhabited the thalli of Squamarina cartilaginea (With.) P. James.

Notes. Clypeococcum psoromatis is abundant in Mediterranean countries (France, Greece, Italy, Portugal and Spain) (Navarro-Rosinés et al., 1994; Etayo, 2010) but is reported for the first time from Ukraine.

EPIBRYON KONDRATYUKII Khodos. \& Darmostuk sp. nov. (Fig. 1)

MycoBank No.: MB 831470

Diagnosis. Morphologically similar to Epibryon casaresii (Bubák \& Gonz. Frag.) Döbbeler but differs by the presence of 0-2-celled paraphysoids $1.0-2.0 \mu \mathrm{m}$ wide, ascospores $(7.0-) 8.3-10.2(-13.0) \times(2.0-) 2.4-3.2(-3.8) \mu \mathrm{m}$ and by being associated with Coccomyxa-like algae on Polytrichum.

Type. Ukraine. Mykolayiv region, Voznesensk district, Aktove village, right bank of the river Mertvovod, Aktovsky valley, 47 $41^{\prime} 41.7^{\prime \prime} \mathrm{N}$ $31^{\circ} 26^{\prime} 21.8^{\prime \prime E}$, alt. $45 \mathrm{~m}$, on algal film over Polytrichum piliferum, on sun-exposed granite outcrops, 1 May 2016, A. Khodosovtsev \& V. Darmostuk (KHER 10017 - holotype, KHER 10007-10016 - isotypes).

Description. Vegetative hyphae loosely intermixed with algal cells, without visible intracel- lular haustoria, c. 2-3(-4) $\mu \mathrm{m}$ thick, light brownish in gelatinous film and medium brown below ascomata; Chlamydospora-like cells medium brown, forming short chains, one- or two-celled 6-9 × 3-5 $\mu \mathrm{m}$; pseudothecia sessile or immersed in algal film, globose, dark-brown to black, setose, closed, (20-)35-85(-90) $\mu \mathrm{m}(n=25)$ diam.; ostiole brown, indistinct; perithecial wall composed of angular pseudoparenchymatous cells (textura angularis) in cross section, c. $7-10 \mu \mathrm{m}$ thick, cells medium brown, angular in squash preparation, (3.0-)3.4-3.8(-5.3) $\mu \mathrm{m}(n=20)$ wide with dark brown pigment deposited in the cell walls; setae dark brown, up to $50 \mu \mathrm{m}$ on upper half of ascomata, erect, straight to somewhat curved, unbranched, subcylindrical to mostly narrowed from base to top, (11-)18-32(-40) $\times$ $(2.0-) 3.0 \pm 4.6(-6.0) \mu \mathrm{m}(n=30)$ in medium part, c. 4-6 $\mu \mathrm{m}$ wide below and 2-3 $\mu \mathrm{m}$ wide above, 0-1-septate, thick-walled, smooth, apex more less acute; hamathecium usually invisible, formed of short 0-2-celled paraphysoids at the base of asci, 1.0-2.0 $\mu \mathrm{m}$ wide; asci 8-spored, fissitunicate, clavate, (21-)24-28(-31) × (7.0)7.4-8.6(-10) $\mu \mathrm{m}(n=15)$, apex wall $2-6 \mu \mathrm{m}$ thick, $\mathrm{K} / \mathrm{I}-$; ascoplasma I+ orange; ascospores hyaline,

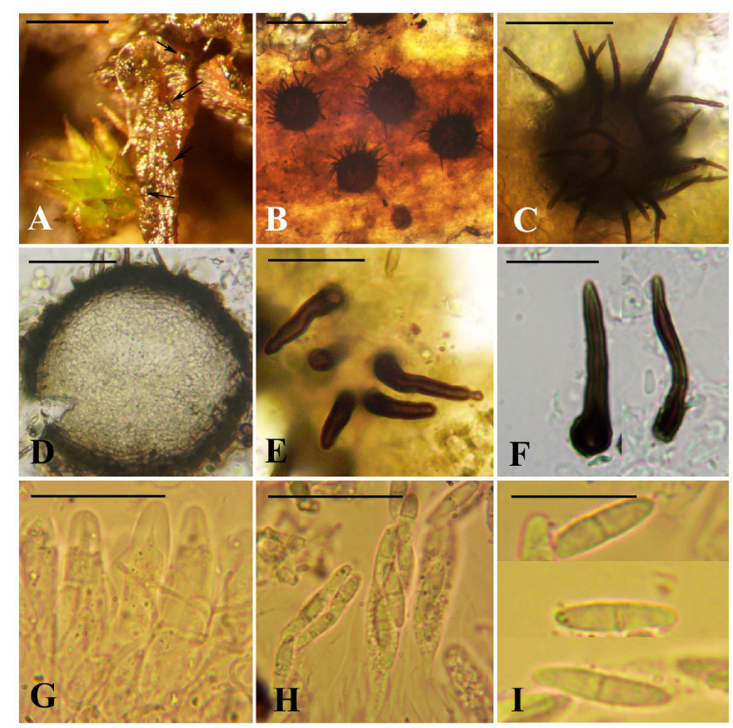

Fig. 1. Epibryon kondratyukii (all from holotype): A, B, C - pseudothecia on the host; D - crosssection of pseudothecium; E, F- setae; G - asci with paraphysoids; $\mathrm{H}, \mathrm{I}$ - ascospore. Scale bars: A $-1 \mathrm{~mm}, \mathrm{~B}-100 \mu \mathrm{m}, \mathrm{C}-50 \mu \mathrm{m}, \mathrm{D}, \mathrm{E}, \mathrm{F}, \mathrm{G}$, $\mathrm{H}-25 \mu \mathrm{m}, \mathrm{I}-10 \mu \mathrm{m}$. 
0-1-septate, subclavate, without appendages, not ornamented, upper cell shorter and broader then lower cell, (7.0-)8.3-10.2(-13.0) × (2.0-)2.4 $3.2(-3.8) \mu \mathrm{m}$, length/width $(2.5-) 2.8-3.6(-4.8)$ $(n=40)$. Pycnidia not seen.

Ecology and distribution. The species formed extensive blackish areas (if dry) on Coccomyxalike algal films on leafs of Polytrichum piliferum in exposed places over granite outcrops. Evidently, the biological nature of this fungus (whether mutualistic or commensal) is similar to the algicolous Epigloea species (Döbbeler, 1984). The vegetative hyphae of Epibryon kondratyukii envelop the living algal sheaths without visible intracellular haustoria. Likewise, dead algal cells were not found in the fresh material. Probably, fungal hyphae adsorb the gelatinous substance produced by the algal cells. The species is known only from type location in the steppe zone of Ukraine so far.

Etymology. The epithet honours the Ukrainian lichenologist Sergiy Kondratyuk at the occasion of his 60th birthday.

Notes. The morphology of new species is similar to other known Epibryon species. Döbbeler (1978) proposed this genus for bryosymbiont species, with the type species E. plagiochilae (Gonz. Frag.) Döbbeler. This species is characterized by setose small globose ascomata, fissitunicate asci with two-celled hyaline ascospores and the absence of paraphysoids. However, the genus includes species with paraphysoids, nonsetose ascomata and brownish ascospores as well. During a molecular study (Stenroos et al., 2010), the type species and some other Epibryon taxa fell into the class Eurotiomycetes, and came out as polyphyletic. Hyde et al. (2013) included the genus in Dothideomycetes and associated it with Pseudoperisporiaceae, the species of which have branched, septate pseudoparaphyses in a gelatinous matrix. The last features are not characters for the type species of Epibryon. The morphology of Epibryon is similar to genus Antennulariella, and a differentiation can be found in the ascomatal setae length. The type species of the genus, A. fuliginosa Woron., described from Ilex leaves in the Caucasus, has a thick non-lichenized mycelium 400-500 $\mu \mathrm{m}$ thick, pseudothecia 60-75 $\mu \mathrm{m}$ diam., ascomatal septate appendages similar to setae up to 100 $\mu \mathrm{m}$ length and a foliicolous habit (Woronichin,
1915). Unfortunately, molecular data for Antennulariella species are missing (Hyde et al., 2013; Chomnunti et al., 2014) and the genus is formally included in Dothideomycetes. Short ascomatal setae are also formed in Niesslia (e.g. Etayo et al., 2013), which includes a few lichenicolous representatives (Diederich et al., 2018). However, this genus has unitunicate, longer asci and larger ascomata. Wentiomyces is similar to the lichenized species of Antennulariella by having hyaline, 1-septate ascospores produced in fissitunicate asci, but the ascomatal setae in the type species, Wentiomyces javanicus Koord. (Koorders, 1907) are dichotomously branched at the apex.

Epibryon kondratyukii morphologically resembles E. casaresii (Bubák \& Gonz. Frag.) Döbbeler, which grows directly on moss leafs (Barbilophozia, Frullania, Mnium, Mylia, Pogonatum, Scapania, Sphagnum, Tritomaria) (Döbbeler, 1978), but differs by the presence of paraphysoids and by being associated with Coccomyxa-like algae on Polytrichum. Epibryon bryophilum (Fuckel) Döbbeler has larger ascospores (15-18 × 6.5-7.5 $\mu \mathrm{m}$ vs. $7-13 \times 2-3.8 \mu \mathrm{m}$ in E. kondratyukii). E. polyphagum Döbbeler is another species associated with green algae and mosses (Racomitrium) (Döbbeler, 1978), but differs from $E$. kondratyukii by asetose lager ascomata and longer ascospores (11-14 $\mu \mathrm{m}$ vs. $7.0-13 \mu \mathrm{m}$ in E. kondratyukit). Paraphysoids are present only in E. dicrani (Racov.) Döbbeler, but this species has shorter ascospores $(7.5 \times 2.5 \mu \mathrm{m}$ vs. $7-13 \times$ 2.0-3.8 $\mu \mathrm{m}$ in E. kondratyukii) and is associated with Dicranum scoparium Hedw. The new species is morphologically similar to the lichenized, corticolous Antennulariella lichenisata Coppins $\&$ Aptroot, which has longer ascospores (13-16 $\mu \mathrm{m}$ vs. $7-13 \mu \mathrm{m}$ in E. kondratyukii), wider asci (10-13.5 $\mu \mathrm{m}$ vs. $7-10 \mu \mathrm{m}$ in E. kondratyukii) and a Trentepohlia photobiont (Coppins \& Aptroot, 2008).

*Epithamnolia Rangiferinae E. Zimm., Diederich \& Suija (Fig. 2 A, B, C)

Specimen examined. Ukraine. Kherson region, Oleshky district, near Nechaevo village, 46³4'06.6”'N $32^{\circ} 46$ '53.2"E, alt. $13 \mathrm{~m}$, on Cladonia foliacea (Huds.) Willd., on sand, 12 April 2018, V. Darmostuk (KHER 11639).

Notes. This recently described species (Suija et al., 2017) has superficial cupulate brown con- 
idiomata (60-)65-85(-105) $\mu \mathrm{m}(\mathrm{n}=15)$, hyaline septate conidiophores developing in the base of the conidiomata, hyaline phialidic lageniform to fusiform conidiogenous cells and aseptate short bacilliform conidia (3.8-)4.4-5.6(-6.0) $\times$ (1.2-) 1.4-1.8(-2.0) $\mu \mathrm{m}$, length/breadth ratio is $(2.4-) 2.8-3.6(-4.2)(\mathrm{n}=30)$. Our specimen has longer conidiogenous cells ((12.4-) 14.2$16.0(-18.8) \times(1.6-) 2.0-2.2(-2.4) \mu \mathrm{m}(\mathrm{n}=30)$ vs. (9.5-)10.4-12.4(-13.3) $\mu \mathrm{m}$ in protologue) and grows on the thallus of Cladonia foliacea vs. Cladonia rangiferina (L.) Weber ex F.H. Wigg. Some decolorisation of infected thalline parts was observed. Cladonia foliacea is a new host species. The fungus was previously known only from Austria and Switzerland (Suija et al., 2017; Zimmermann \& Berger, 2018).

*Katherinomyces cetrariae Khodos. (Fig. 2 D, E, F, G)

Specimens examined. Ukraine. Zaporizzia region, Chernihiv district, near Novopoltavka village, $47^{\circ} 15^{\prime} 00.1^{\prime} \mathrm{N} 36^{\circ} 17 ' 30.7^{\prime} \mathrm{E}$, alt. $46 \mathrm{~m}$, on granite stone, 2 October 2007, A. Khodosovtsev, T. Zavyalova (KHER 4401, 4363); near Kamianka village, $47^{\circ} 14^{\prime} 20.5^{\prime} \mathrm{N} 36^{\circ} 00^{\prime} 10.7^{\prime} \mathrm{E}$, alt. $42 \mathrm{~m}$, on granite stone, 19 July 1995, A. Khodosovtsev (KHER 6387). Both specimens inhabited the thalli of Lecidea fuscoatra (L.) Ach.

Notes. Our specimens are characterized by an immersed light brown vegetative mycelium (2.2-)3.0-4.2(-4.6) $\mu \mathrm{m}(n=30)$ thick, erumpent black globose conidiomata opening irregularly (90-)95-100(-110) $\mu \mathrm{m}(n=10)$ diam., a brownish thin conidiomatal wall up to $5 \mu \mathrm{m}$ thick. Conidiophores indistinct. Conidiogenous cells brown, ellipsoid, slightly verrucose, (5.0-)5.6-7.6(-8.4) $\times$ (2.2-)3.0-5.6(-6.2) $\mu \mathrm{m}(n=30)$. Conidia aseptate, broadly ellipsoid to irregular, brown, verrucose, (6.6-)9.2-10.4(-12.0) × (3.2-)4.0-5.2(-6.0) $\mu \mathrm{m}$, length/breadth ratio (1.3-)2.0-2.4(-3.2) ( $\mathrm{n}=60)$. Infected thalli become whitish due to damage of the upper cortex. The specimens differ from the type description by bigger conidiomata (vs. 30-50 $\mu \mathrm{m}$ in holotype). Originally, the species was known only on Cetraria aculeata (Schreb.) Fr., on which it does not cause any damage (Khodosovtsev et al., 2016, 2018). The examined specimens suggest that Katherinomyces cetrariae is able to parasitize unrelated host species, however, more studies, including molecular data are needed to ascertain that populations on different hosts belong to the same species.

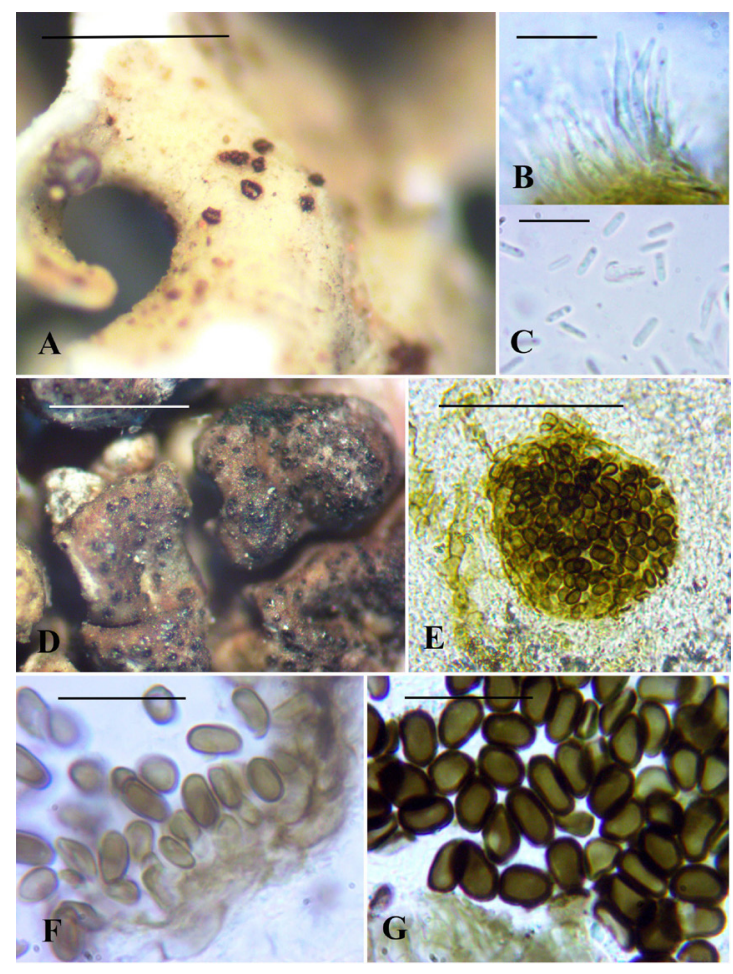

Fig. 2. Epithamnolia rangiferinae (KHER 11639): A - conidiomata on host thallus; B - conidiogenous cells; $\mathrm{C}$ - conidia. Katherinomyces cetrariae (KHER 4401): D - conidiomata on host thallus; $\mathrm{E}$ - cross-section of conidioma (in K); F - conidiogenous cells with conidia; $\mathrm{G}$ - conidia (in $\mathrm{K}$ ). Scale bar: A, D - 1mm, E- $100 \mu \mathrm{m}, \mathrm{F}, \mathrm{G}-20$ $\mu \mathrm{m}, \mathrm{B}, \mathrm{C}-10 \mu \mathrm{m}$.

\section{*Lawalreea lecanorae Diederich}

Specimens examined. Ukraine. Kherson region, Bilozerka district, near Stanislav village, 46 $34^{\prime} 35.2^{\prime \prime} \mathrm{N}$ $32^{\circ} 11^{\prime} 02.4^{\prime \prime} \mathrm{E}$, alt. $9 \mathrm{~m}$, on Ephedra, 30 May 2017, A. Khodosovtsev, V. Darmostuk (KHER 11318); Kalanchak district, Khorly village, $46^{\circ} 04^{\prime} 52.8^{\prime \prime} \mathrm{N}$ $33^{\circ} 17^{\prime} 57.2$ ” E, alt. $9 \mathrm{~m}$, on Populus, 8 August 2017, V. Darmostuk (KHER 11316). Both specimens inhabited the apothecia of Myriolecis hagenii (Ach.) Śliwa, Zhao Xin \& Lumbsch.

Notes. Previously, the species was reported on apothecia of corticolous Lecanora species from Spain, France, Luxembourg, Germany, Poland and Russia (Boqueras, 2000; Diederich, 1990; Jando \& Kukwa, 2003; Kocourková \& Brackel, 2005; Signoret \& Diederich, 2003; Zhurbenko $\&$ Notov, 2015). 
*Llimoniella adnata Hafellner \& Nav.-Ros.

Specimen examined. Ukraine. Kherson region, Velyka Oleksandrivka district, near Bilohorka village, right bank of river Ingulets, $47^{\circ} 12 ' 21.41^{\prime \prime} \mathrm{N} 33^{\circ} 08^{\prime} 03.81^{\prime \prime} \mathrm{E}$, alt. $41 \mathrm{~m}$, on green algal crust, on soil, 2 May 2017, G. Naumovych (KHER 11654).

Notes. The specimen is characterized by semiimmersed to sessile roundish marginate apothecia (150-)165-180(-195) $\mu \mathrm{m}$ diam., an orange brown exciple without hairs, $\mathrm{K}+$ shortly violet, hyaline hymenium up to $100 \mu \mathrm{m}, 8$-spored cylindrical asci and hyaline aseptate ellipsoid ascospores with 1-2 big guttules, (9.8-)11.2$13.4(-13.8) \times(4.8-) 5.5-6.5(-7.0) \mu \mathrm{m}$, length/ breadth ratio (1.6-)2.0-2.4(-2.8) $(n=40)$.

This species has been collected on a cyanobacterial soil crust under destroyed lichen thalli. Probably, the host is Placidium squamulosum (Ach.) Breuss because this species is also known from this location. Llimoniella adnata was reported from Spain and Russia (Diederich \& Etayo, 2000).

\section{*Merismatium decolorans (Rehm ex Arnold) Triebel}

Specimen examined. Ukraine. Kherson region, Novotroitsk district, Churyuk Island, $46^{\circ} 05^{\prime} 01.4^{\prime \prime} \mathrm{N}$ $34^{\circ} 15^{\prime} 30.7^{\prime \prime} \mathrm{E}$, alt. $5 \mathrm{~m}$, on Cladonia sp., on soil, 6 October 2018, V. Darmostuk (KHER 12124).

Notes. A common species in Europe with a wide host-specificity, previously known on a few Cladonia species (Zhurbenko \& Pino-Bodas, 2017).

*SphaEREllothecium Cladoniae (Alstrup \& Zhurb.) Hafellner

Specimen examined. Ukraine. Autonomous Republic of Crimea, Sudakskyi district, Cape Meganom, $44^{\circ} 48^{\prime} 41.3$ "N $35^{\circ} 04^{\prime} 48.0^{\prime \prime} \mathrm{E}$, alt. $68 \mathrm{~m}$, on thallus of Cladonia foliacea, on soil, 8 August 2004, A. Khodosovtsev (KHER 12146).

Notes. A widespread species in the Holarctic (e.g. Zhurbenko \& Pino-Bodas, 2017). The infected thallus parts in our specimen turn whitish.

\section{*Stigmidium Bellemerei Cl. Roux \& Nav.-Ros.}

Specimen examined. Ukraine. Kherson region, Bilozerka district, Fedorivka village, 46 $48^{\prime} 18.6^{\prime \prime N}$ $32^{\circ} 48^{\prime} 19.4 " \mathrm{E}$, alt. $25 \mathrm{~m}$, on Lecania turicensis (Hepp) Müll. Arg., on limestone, 13 June 2018, V. Darmostuk (KHER 11631).

Notes. This species has been reported from France, Germany, Luxembourg and Czech Republic (Roux et al., 1998; Sérusiaux et al.,
1999; Triebel \& Scholz, 2001; van den Boom \& Palice, 2006).

*Stigmidium Ramalinae (Müll. Arg.) Etayo \& Diederich

Specimen examined. Ukraine. Kherson region, Oleshky district, Kozachi Lagery, Pokosy, 46³6’19.5”N $32^{\circ} 56^{\prime} 46.0$ "E, alt. $32 \mathrm{~m}$, on Ramalina fraxinea (L.) Ach., on Populus bark, 20 March 2008, A. Khodosovtsev (KHER 11655).

Notes. Vegetative mycelium immersed in the host thallus, brown, smooth walled, (5.4-)5.6$6.0(-6.4) \mu \mathrm{m}$ wide. Ascomata scattered, black globose, (45-)50-55(-65) $\mu \mathrm{m}(n=15)$. Ascomatal wall brown, 5-8 $\mu \mathrm{m}$ thick, composed of two layers of elongate cells, textura angularis. Ostiolar and interascal filaments not observed. Asci bitunicate, clavate with thick apical part, 8-spored, (20.0-)22.4-26.6(-28.6) × (7.6-)12.2-13.8(-14.6) $\mu \mathrm{m}(n=15), \mathrm{BCr}+$ blue, I-. Ascospores colourless, surface smooth, with visible halo, ellipsoid with slightly wider upper cell, 1-septate (overmature ascospores 3-septate), slightly constricted at the septa, (10.8-)11.6-13.0(-14.2) × (3.2-)3.4-4.0(4.6) $\mu \mathrm{m}$, length/breadth ratio (2.4-)3.0-3.6(-4.4) $(n=35)$.

There are two Stigmidium species known on $\mathrm{Ra}$ malina species: Stigmidium epiramalina (Vouaux) Hafellner and Stigmidium ramalinae (Müll. Arg.) Etayo \& Diederich. As the protologues of both species have only minor differences in spore size, some authors consider them as synonyms (e.g., Etayo \& Osorio, 2004). The situation is complicated by the fact that the type specimen of Stigmidium epiramalina (= Pharcidia epiramalina Vouaux) seems to be lost. Our specimen perfectly fits the detailed description provided by Etayo \& Osorio (2004) for Stigmidium ramalinae.

Stigmidium ramalinae is a widespread species reported from Europe, Asia, South and North America (Hafellner, 1994; Hawksworth, 2003; Etayo \& Osorio, 2004; van den Boom \& Etayo, 2006; Etayo \& Sancho, 2008; Kocourková et al., 2010; Kondratyuk et al., 2016).

*Weddellomyces epicallopisma (Wedd.) D. Hawksw.

Specimens examined. Ukraine. Autonomous Republic of Crimea, Edykuy (Leninskyi) district, near Mts Opuk, 4502'33.0”N 36¹3'30.7”E, alt. $65 \mathrm{~m}$, on Variospora aurantia (Pers.) Arup, Frödén \& Søchting, on limestone, 9 June 1983, E. Kopachevska, N. Beznis (KW 53290); Kherson region, Bilozerskyi district, near 
Olexandrivka village, 4640'10.5”N 3206'30.3"E, alt. 20 m, on Flavoplaca austrocitrina (Vondrák, Řiha, Arup \& Søchting) Arup, Søchting \& Frödén, on concrete in channel, 9 January 2018, V. Darmostuk (KHER 11653); Velyka Oleksandrivka district, village Mala

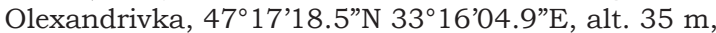
on Caloplaca sp., on limestone, 29 September 2018, V. Darmostuk (KHER 12137).

Notes. This species has been reported on the thallus and apothecia of Variospora aurantia from Germany (Hawksworth \& Diederich, 1991), Spain (Navarro-Rosinés \& Roux, 1995), France (Weddell, 1873), British Isles (Hawksworth, 1986), Italy (Nimis \& Poelt, 1987) and Israel (Calatayud \& Navarro-Rosinés, 1998). Flavoplaca austrocitrina is a new host species.

\section{ACKNOWLEDGMENTS}

We express our gratitude to Brian Coppins and Paul Diederich for a discussion on the new species and linguistic correction. Vitalii Kolomiychuk, Ganna Naumovych, Olha Sira and Olexandr Yurchenko were of indispensable assistance during fieldwork excursions. This study was financially supported by the Ministry of Science and Education of Ukraine (Project No 0219U000270).

\section{REFERENCES}

Arnold, F. 1879. Lichenologische Ausflüge in Tirol. XX. Predazzo. Verhandlungen der kaiserlichköniglichen zoologisch-botanischen Gesellschaft in Wien 29: 351-394.

Boqueras, M. 2000. Liquens epifits ifongs liquenícoles del sud de Catalunya: flora $i$ comunitats. Barcelona, Institut d'Estudis Catalans (Arxius de les Seccions de Ciêncies 127, Secció de Ciències Biològiques).

Calatayud, V. \& Navarro-Rosinés, P. 1998. Weddellomyces xanthoparmeliae sp. nov. and additions to the chorology of other species of the genus. Mycotaxon 69: 503-514.

Chomnunti, P., Hongsanan, S., Aguirre-Hudson, B., Tian, Q., Peršoh, D., Dhami, M. K., Alias A. S., Xu, J., Liu X., Stadler, M. \& Hyde, K. D. 2014. The sooty moulds. Fungal Diversity 66(1): 1-36. https:/ / doi.org/10.1007/s13225-014-0278-5

Coppins, B. \& Aptroot, A. 2008. New species and combinations in The Lichens of the British Isles. The Lichenologist 40(5): 363-374. https://doi. org/10.1017/S0024282908008165

Darmostuk, V. V. \& Khodosovtsev, A. Y. 2017. Lichenicolous fungi of Ukraine: an annotated checklist. Studies in Fungi 2(1): 138-156. https://doi. org/10.5943/sif/2/1/16
Darmostuk, V. V., Khodosovtsev, A. Y., Naumovich, G. O. \& Kharechko, N. V. 2018. Roselliniella lecideae sp. nov. and other interesting lichenicolous fungi from the Northern Black Sea region (Ukraine). Turkish Journal of Botany 42(3): 354-361 https: / / doi.org/ 10.3906/bot-1709-5

Diederich, P. 1990. New or interesting lichenicolous fungi 1 . Species from Luxembourg. Mycotaxon 37: 297-330.

Diederich, P. \& Etayo, J. 2000. A synopsis of the genera Skyttea, Llimoniella and Rhymbocarpus (1ichenicolous Ascomycota, Leotiales). The Lichenologist 32(05): 423-485. https://doi.org/10.1006/ lich.2000.0290

Diederich, P., Lawrey, J. D. \& Ertz, D. 2018. The 2018 classification and checklist of lichenicolous fungi, with 2000 non-lichenized, obligately lichenicolous taxa. The Bryologist 121(3): 340-425. https:/ / doi. org/10.1639/0007-2745-121.3.340

Döbbeler, P. 1978. Moosbewohnende Ascomyceten I. Die Pyrenocarpen, den Gametophyten besiedelnden Arten. Mitteilungen aus der Botanischen Staatssammlung München 14: 1-360.

Döbbeler, P. 1984. Symbiosen zwischen Gallertalgen und Gallertpilzen der Gattung Epigloea (Ascomycetes). Beihefte zur Nova Hedwigia 79: 203-239.

Etayo, J. 2010. Hongos liquenícolas de Perú Homenaje a Rolf Santesson. Bulletin de la Société Linnéenne de Provence 61: 1-46.

Etayo, J., Flakus, A. \& Kukwa, M. 2013. Niesslia echinoides (Niessliaceae, Ascomycota), a new lichenicolous fungus on Erioderma from Bolivia. The Lichenologist 45(1): 21-24. https: / / doi. org/ 10.1017/S0024282912000540

Etayo, J. \& Osorio, H. S. 2004. Algunos hongos liquenícolas de Sudamérica, especialmente del Uruguay. Comunicaciones Botánicas Museos Nacionales de Historia Natural y Antropologia 129(6): 1-19.

Etayo, J. \& Sancho, L. G. 2008. Hongos liquenícolas del Sur de Sudamérica, especialmente de Isla Navarino (Chile). Bibliotheca Lichenologica 98: 1-302.

Hafellner, J. 1994. Über Funde lichenicoler Pilze und Flechten auf Korsika (Frankreich). Bulletin de La Société Linnéenne de Provence 44: 219-234.

Hawksworth, D. 2003. The lichenicolous fungi of Great Britain and Ireland: an overview and annotated checklist. The Lichenologist 35(3): 191-232. https://doi.org/10.1016/S0024-2829(03)00027-6

Hawksworth, D. L. 1986. Notes on British lichenicolous fungi: V. Notes from the Royal Botanic Garden, Edinburgh 43(3): 497-519.

Hawksworth, D. L. \& Diederich, P. 1991. Lichenicolous fungi from the Schwäbische Alb, Baden-Württemberg. Jahreshefte der Gesellschaft für Naturkunde in Württemberg 146: 85-88.

Hawksworth, D. L. \& Kalb, K. 1992. A New Species of Ascochyta on Candelariella aurella from Baja California, Mexico. The Bryologist 95(3): 338-339. https://doi.org/ 10.2307/3243494 
Hyde, K. D., Jones, E. G., Liu, J. K., Ariyawansa, H., Boehm, E., Boonmee, S., Diederich, P., Dissanayake, A., Doilom, M., Doveri, F., et al., \& Zhang M. 2013. Families of Dothideomycetes. Fungal Diversity 63(1): 1-313. https://doi.org/10.1007/ s13225-013-0263-4

Jando, K. \& Kukwa, M. 2003. Porosty, grzyby naporostowe i nazywiczne projektowanego rezerwatu "Wiszace Torfowiska nad jeziorem Jaczno" oraz terenów przyleglych do jeziora Jaczno w Suwalskim Parku Krajobrazowym (Pólnoco-Wschodnia Polska). Parki Narodowe $i$ Rezerwaty Przyrody 22(1): 3-17.

Khodosovtsev A. Y. \& Darmostuk V. V. 2016. New species of lichenicolous fungi for Ukraine. Folia Cryptogamica Estonica 53: 93-99. https://doi. org/10.12697/fce.2016.53.11

Khodosovtsev A. Y. \& Darmostuk V. V. 2017. Zwackhiomyces polischukii sp. nov., and other noteworthy lichenicolous fungi from Ukraine. Polish Botanical Journal 62(1): 27-35. https://doi.org/10.1515/ pbj-2017-0006

Khodosovtsev, A., Darmostuk, V., Suija, A. \& Ordynets, A. 2018. Didymocyrtis trassii sp. nov. and other lichenicolous fungi on Cetraria aculeata. The Lichenologist 50(05): 529-540. https://doi. org/10.1017/S0024282918000294

Khodosovtsev, A. Y., Gavrylenko, L. M. \& Klymenko, V. M. 2016. Katherinomyces cetrariae gen. et sp. nov. (asexual Ascomycota) and Sphaerellothecium aculeatae sp. nov. (Mycosphaerellaceae), new lichenicolous fungi on Cetraria aculeata in Ukraine. Nova Hedwigia 103(1): 47-55. https:// doi.org/10.1127/nova_hedwigia/2016/0333

Kocourková, J. \& Brackel, W. von. 2005. Einige für Bayern neue flechtenbewohnende Pilze-Beitrag zu einer Checkliste I. Berichte der Bayerischen Botanischen Gesellschaft 35: 3-10.

Kocourková, J., Fryday, A. M., Knudsen, K. \& Lendemer, J. 2010. Studies in lichens and lichenicolous fungi: more notes on taxa from North America 6. Mycotaxon 111(1): 423-429. https:// doi.org/ 10.5248/111.423

Kondratyuk, S. Y. \& Khodosovtsev, A. Y. 1997. New for Ukraine species of lichenicolous fungi. Ukrainian Botanical Journal 54(6): 564-569.

Kondratyuk, S. Y., Lökös, L., Halda, J. P., Haji Moniri, M., Farkas, E., Park, J. S., ... Hur, J.-S. (2016). New and noteworthy lichen-forming and lichenicolous fungi 4. Acta Botanica Hungarica 58(1-2): 75-136. https://doi.org/10.1556/034.58.2016.1-2.4

Koorders, S. H. 1907. Botanische Untersuchungen. Verhandelingen Koinklijke Nederlandse Akademie van Wetenschappen Afdeling Natuurkunde 13(4): $1-264$.

Matzer, M. \& Hafellner, J. 1990. Eine Revision der lichenicolen Arten der Sammelgattung Rosellinia (Ascomyceten). Bibliotheca Lichenologica 37: 1-138.
Navarro-Rosinés, P. 1992. Eis liquens $i$ els fongs liquenicoles dels substrats carbonatats de Catalunya meridiona. Tesis Doctoral Univo Barcelona.

Navarro-Rosinés, P. \& Roux, C. 1995. Le genre Weddellomyces (Dothideales, Dacampiaceae) en Catalogne et en Provence. Mycotaxon 53: 161-187.

Navarro-Rosinés, P., Roux, C. \& Llimona, X. 1994. Nelikenigintaj fungoj ce Squamarina: Clypeococcum epicrassum comb. nov. kaj Lichenochora clauzadei sp. nov. (Ascomycetes). Bulletin de La Société Linnéenne de Provence 45: 421-429.

Nimis, P. L. \& Poelt, J. 1987. The lichens and lichenicolous fungi of Sardinia (Italy). Studia Geobotanica 7: 1-269.

Roux, C., Navarro-Rosinés, P. \& Tranchida, F. 1998. Stigmidium bellemerei sp. nov., champignon lichénicole non lichénisé (Verrucariales). Cryptogamie., Bryologie.-Lichénologie 19(2-3): 221-228.

Sérusiaux, E., Diederich, P., Brand, A. M. \& van den Boom, P. P. G. 1999. New or interesting lichens and lichenicolous fungi from Belgium and Luxembourg. VIII. Lejeunia 162: 1-95.

Signoret, J. \& Diederich, P. 2003. Inventaire des champignons lichénisés et lichénicoles de la Réserve Naturelle des rochers et tourbières du Pays de Bitche. Annales Scientifiques de La Réserve de Biosphère Transfrontalière Vosges Du NordPfälzerwald 11: 193-222.

Stenroos, S., Laukka, T., Huhtinen, S., Döbbeler, P., Myllys, L., Syrjänen, K. \& Hyvönen, J. 2010. Multiple origins of symbioses between ascomycetes and bryophytes suggested by a five-gene phylogeny. Cladistics 26(3): 281-300. https:/ / doi. org/10.1111/j.1096-0031.2009.00284.x

Suija, A., van den Boom, P., Zimmermann, E., Zhurbenko, M. P. \& Diederich, P. 2017. Lichenicolous species of Hainesia belong to Phacidiales (Leotiomycetes) and are included in an extended concept of Epithamnolia. Mycologia 109(6): 882-899. https://doi.org/10.1080/00275514.2017.1413891

Triebel, D. \& Scholz, P. 2001. Lichenicolous fungi from Bavaria as represented in the Botanische Staatssammlung München. Sendtnera 7: 211-231.

van den Boom, P. P. G. \& Etayo, J. 2006. New records of lichens and lichenicolous fungi from Fuerteventura (Canary Islands), with descriptions of some new species. Cryptogamie, Mycologie 27: 341-374.

van den Boom, P. P. G. \& Palice, Z. 2006. Some interesting lichens and lichenicolous fungi from the Czech Republic. Czech Mycology 58(1-2): 105-116. https://doi.org/10.33585/cmy.58108

Weddell, H.-A. 1873. Nouvelle revue des lichens du jardin de Blossac, à Poitiers. Mémoires de la Société des Sciences Naturelles de Cherbourg 17: 353-373.

Woronichin, N. N. 1915. Les fumagines du département de Sotshi. Trudy Byuro po Prikladnoi Botanike. 8: 769-807. 
Zhurbenko, M. \& Notov, A. 2015. The lichenicolous lichen Placocarpus americanus and some noteworthy lichenicolous fungi from Russia. Folia Cryptogamica Estonica 52: 95-99. https://doi. org/ 10.12697/fce.2015.52.12

Zhurbenko, M. P. \& Pino-Bodas, R. 2017. A revision of lichenicolous fungi growing on Cladonia, mainly from the Northern Hemisphere, with a worldwide key to the known species. Opuscula Philolichenum 16: $188-266$.

Zimmermann, E. \& Berger, F. 2018. Ein Beitrag zur Kenntnis der Lichenicolen Mycobiota Österreichs. Funde aus Tirol I. Herzogia 31(1): 732-762. https://doi.org/10.13158/heia.31.1.2018.732 